\title{
LABOR LAW: HIRING OF TEMPORARY REPLACEMENTS SUBSEQUENT TO MULTI-EMPLOYER LOGKOUT HELD NOT TO CONSTITUTE AN UNFAIR LABOR PRACTICE
}

$\mathrm{U}_{\text {NDER }}$ the Taft-Hartley Act it is an unfair labor practice for employers to discourage membership in a labor organization by discrimination in regard to hire or tenure. ${ }^{1}$ In the recent case of $N L R B$ v. Brown, ${ }^{2}$ a divided court held that the hiring of temporary replacements by nonstruck members of a multi-employer association did not violate the act, despite the fact that the employers had initially locked out regular union clerks to avoid the effects of a whipsaw strike. ${ }^{3}$

In Brown, employers of seven retail food stores had joined together for the purpose of bargaining as a unit with a common labor union. ${ }^{4}$ When contract negotiations reached a bargaining impasse,

${ }^{1}$ Labor Management Relations Act (Taft-Hartley Act) $\$ 8$ (a) (3), 61 Stat. 140 (1947), 29 U.S.C. $\$ 158(a)(3)$ (1958). Also at issue in the instant case was $\S 8$ (a) (1) of the act, which prohibits an employer from interfering with employees' rights of self-organization and collective bargaining. 61 Stat. 140 (1947), 29 U.S.C. $\$ 158$ (a) (1).

2319 F.2d 7 (10th Cir. 1963), cert. granted, 32 U.S.L. WeEK 3237 (U.S. Jan. 7, 1964).

${ }^{3}$ Before the formation of a multi-employer association, a labor union has the advantage of striking employers individually, insofar as a struck employer cannot afford a prolonged detachment from his competitive market. The longer he remains inoperative, the more customers he stands to lose to competitors. The whipsaw technique is a series of successive strikes against individual members of a multiemployer association. Its purpose is to return the struck individual to his pre-association condition by isolating him economically from his fellow employers. Unless he can find replacements, the situation is cured only by the exercise of a bargaining lockout on the part of all employers, for once a struck employer concludes a contract, he has no further interest in group bargaining. Concessions gained by the union in a rapid settlement establish a standard imposed upon successively struck employers. Thus the whipsaw most often originates against the weakest link in the association.

The whipsaw enjoys particular effectiveness among associations with an interdependent wage structure, and where competition among employers is keen. Although courts have evinced a concern for containing the disintegrating effects of a whipsaw strike, it should be noted that the technique is by no means illegal. NLRB v. Anchorage Businessmen's Ass'n, 289 F.2d 619, 622 (9th Cir. 1961).

- The union involved was Local 462 of the Clerks International Association, the recognized bargaining agent of all clerks employed by the multi-employer unit. Hence, there was no problem of discrimination due to locking out only union members while nonunion employees retained their job status. For a case where there was such a prohlem, see NLRB v. Anchorage Businessmen's Ass'n, supra note 3.

It should also be noted that no question is raised in this case of a violation of $\S$ 8 (a) (5) of the act by a refusal to bargain in good faith. 61 Stat. 140 (1947), 29 U.S.C. $\$ 158$ (a) (5) (1958). For such a case see, e.g., NLRB v. Insurance Agents' Int'I Union, 361 U.S. 477 (1960). 
the union initiated a whipsaw strike against Food Jet, one member of the employer unit. All other association members immediately locked out their clerical employees, but when Food Jet replaced its economic strikers, the nonstruck employers also hired temporary replacements. Only one nonstruck member was unable to continue operations. Bargaining continued until an agreement was concluded, whereupon all employees were reinstated. Upon action instituted by the union, the NLRB ruled in a 3-2 decision ${ }^{5}$ that the valid defensive nature of the lockout was vitiated by the subsequent discriminatory act of replacing employees who had remained willing to work on their employers' terms. The Board reasoned that while the initial lockout was privileged under Supreme Court precedent, ${ }^{\circ}$ the subsequent hiring of replacements rendered it "retaliatory" since the association could retain competitive equality among all employers by the reinstatement of nonstriking union clerks. ${ }^{7}$

In denying enforcement of the Board's order, the Court of Appeals for the Tenth Circuit concluded that although an intent to discriminate may be properly inferred from the hiring of nonunion replacements, a consideration of the overriding business purpose justifies the lockout-replacement procedure. ${ }^{8}$ As this court inter-

\footnotetext{
- Brown Food Store, 137 N.L.R.B. 73 (1962), 37 N.Y.U.L. REv. 1152.

- Buffalo Linen Supply Co., 109 N.L.R.B. 447 (1954), enforcement denied sub nom., Truck Drivers Local 449 v. NLRB, 231 F.2d 110 (2d Cir. 1956), rev'd, 353 U.S. 87 (1957), 43 A.B.A.J. 543 (1957), 57 Colum. L. REv. 1172 (1957), 20 GA. B.J. 422 (1958), 71 HARv. L. REv. 182 (1957), 36 Texas L. Rev. 105 (1957), 42 VA. L. REv. 684 (1956), 11 VAND. L. REv. 246 (1957).

7 Members Rogers and Fanning dissented on three grounds. Their first contention, that temporary replacement does not jeopardize job status or union affiliation, was not raised on appeal; the second, that the lockout reduces all union clerks to economic strikers, was affirmatively rejected. The appellate decision, however, did accept their third argument to the effect that the majority NLRB order renders illusory the right to lockout granted by the Supreme Court in Buffalo Linen, supra
} note 6 .

${ }^{8}$ Normally the NLRB must show substantial evidence of a subjective iutent to discriminate before an act is held to constitute an unfair labor practice. However, if the natural consequences of the employer's conduct tend to be inherently dis. criminatory, proof of actual subjective intent is not necessary as the employer will be deemed to have intended foreseeable consequences. NLRB v. Erie Resistor Corp., 373 U.S. 221, 228 (1963); Local 357, Int'l Bhd. of Teamsters v. NLRB, 365 U.S. 667, 675 (1961); Radio Officers' Union v. NLRB, 347 U.S. 17, 44-45 (1954).

Once inherently discriminatory action is found to exist, it is barred by the act "unless saved from illegality by an overriding business purpose justifying the invasion of union rights." NLRB v. Erie Resistor Corp., supra at 231. It is necessary that such action either advance or protect a legitimate interest. See NLRB v. Truck Drivers Local 449, 353 U.S. 87 (1957); NLRB v. Babcock \& Wilcox Co., 351 U.S. 105 (1956); Utah Plumbing \& Heating Contractors Ass'n v. NLRB, 294 F.2d 165 (10th Cir. 1961). 
preted established precedent," employers may resort to "self-help" to preserve unity of economic condition among members of a bargaining association faced with a whipsaw strike. ${ }^{10}$ Since the struck employer may replace economic strikers under the Mackay doctrine, 11 the court reasoned that the privilege of lockout granted to nonstruck associates is rendered illusory if they cannot also temporarily replace. This procedure, although a discriminatory interference with protected union activity, was in the court's opinion necessary to maintain group economic unity. ${ }^{12}$ The court carefully stipulated, however, that the locked out employees were not placed in the status of actual strikers. ${ }^{13}$

The multi-employer association has long been utilized by small, competitive firms to consolidate their bargaining strength in juxtaposition to a common union. These groups tend to eliminate inequality of wage scales while providing management with a unified

\footnotetext{
- See case cited note 6 supra.

${ }^{10}$ The Tenth Circuit had previously held that a multi-employer lockout is privileged only after actual initiation of the whipsaw strike, and not in mere anticipation therecf. Utah Plumbing \& Heating Contractors Ass'n v. NLRB, 294 F.2d 165 (10th Cir. 1961).

11 NLRB v. Mackay Radio \& Tel. Co., 304 U.S. 333 (1938). Under the Mackay doctrine, an employer may replace economic strikers because of his interest in protecting and continuing his business. 304 U.S. at 345. Replacement and partial reinstatement by struck employers constitutes an unfair labor practice only if those omitted from reinstatement are selected due to their union activity. 304 U.S. at 345-47.

The rigbt of replacement is still restricted by $\$ \S 8$ (a) (1), (3) of the Taft-Hartley Act. See NLRB v. Erie Resistor Corp., 373 U.S. 221 (1963) ("super-seniority" plan for replacements constitutes unfair labor practice).

12 To be violative of $\S 8$ (a) (3) an act must be both discriminatory and calculated to discourage or encourage membership in a labor union. Either element standing alone is insufficient. Radio Officers' Union v. NLRB, 347 U.S. 17, 42-43 (1954); NLRB v. Dalton Brick \& Tile Corp., 301 F.2d 886, 896 (5th Cir. 1962). Discriminatory action has been held to mean "selective" in the sense of favoring one group of people over ancther. NLRB v. Great Falls Employers' Council, Inc., 277 F.2d 772, 775 (9th Cir. 1960). The hiring of replacements is discriminatory when automatically excluding all available union personnel, and it has been recognized that when membership in a union is all that precludes employment during a lockout, the laycff is calculated to discourage union membership. NLRB v. Anchorage Businessmen's Ass'n, 289 F.2d 619, 622 (9th Cir. 1961). Although discriminatory action can only be justified by showing that it promotes a legitimate employer interest, there is no burden of presumptive illegality cast upou the employer. NLRB v. Dalton Brick \& Tile Corp., supra at 894.

${ }^{13} 319$ F.2d at 11 . This statement rejects an opinion expressed by two dissenting members of the NLRB, see note 7 supra, and by strong implication restricts the procedure adopted in Brown to temporary as opposed to a permanent right of replacement subsequent to a multi-employer lockout. If the struck member is only able to hire permanent replacements, it would appear that nonstruck members must either find temporary replacements or remain inoperative. Unity of association is apparently not so significant an interest that it justifies the outright dismissal of nonstriking employees.
} 
front to resist "take it or leave it" union demands. ${ }^{14}$ To dissever the employer unit, unions have exercised the whipsaw technique of successive strikes against individual members. The inability to operate while competitors reap the fruits of his lost market often contributes to an early capitulation by the struck member, resulting in a separate contract granting benefits in excess of those contemplated by the association. To combat the disintegrating effects of a whipsaw, nonstruck members have in turn resorted to the bargaining lock. out. ${ }^{15}$

The legitimate use of the lockout was clarified to some extent by the Buffalo Linen case ${ }^{16}$ in which the Supreme Court recognized the legitimacy of preserving the unity of a multi-employer association. In Buffalo Linen the NLRB's ruling that a multi-employer lockout was privileged if defensive in nature was rejected by the Second Circuit which stressed the necessity for showing economic hardship imposed on individual firms. ${ }^{17}$ In upholding the original order of the Board, the Supreme Court determined that the Taft-Hartley Act does imply the legitimacy of a lockout under certain unspecified

\footnotetext{
14 Unions have consented to deal with multi-employer associations because bargaining with an industry wide unit tends to minimize administrative expenses and standardize wages scales, as well as provide security against raiding by rival unions. It is also recognized that the consumer benefits since strikes within multi-employer units tend to occur less frequently than otherwise. Truck Drivers Local $449 \mathrm{v}$. NLRB, 231 F.2d 110, 119-20 \& n.4 (2d Cir. 1956) (dissenting opinion), rev'd, 353 U.S. 87 (1957). The Supreme Court has refused to determine whether a union is accorded the same right of withdrawal from the multi-party bargaining unit as is accorded individual employers. NLRB v. Sklar, 316 F.2d 145 (Gth Cir. 1963); Koretz, The Multi-Employer Lockout Vindicated, 9 SYRAcuse L. REv. 40, 43 (1957).

Multi-employer associations have raised antitrust questions; see, e.g., Clune v. Publishers' Ass'n, 214 F. Supp. 520 (S.D.N.Y.), aff'd mem., 314 F.2d 343 (2d Cir, 1963). Due to express statutory language, in the absence of an express violation of the Sherman Act $\S 1$, cases arising out of a bona fide labor dispute will not warrant injunctive rehef against the formation of a multi-employer association notwithstanding the interruption of commerce arising from a resultant strike. Sherman Act $\$ 1$, 50 Stat. 693 (1937), as amended, 69 Stat. 282 (1955), 15 U.S.C. $\S 1$ (1958); AntiInjunction Act of 1932 (Norris-La Guardia Act) $\$ \$ 4,7,13,47$ Stat. 70-73, 29 U.S.C. $\$ \$ 104,107,113$ (1958).

${ }^{15}$ The lockout may be generally defined as a temporary layoff of employees de. signed to improve an employer's bargaining or economic position. Its legality depends upon the particular circumstances of its use. Prior to Buffalo Linen lockouts were legal only when necessary to avoid economic loss. See generally, Koretz, Legality of the Lockout, 4 SYRAcUSE L. REv. 251 (1953); Koretz, The Lockout Revisited, 7 SYRACUSE L. REv. 263 (1956); Koretz, The Multi-Employer Lockout Vindicated, 9 SYRACUSE L. REv. 40 (1957); Meltzer, Single-Employer and Multi-Employer Lockouts Under the Taft-Hartley Act, 24. U. CHI. L. REV. 70 (1956).

${ }^{18} 353$ U.S. 87 (1957).

${ }^{17}$ See note 15 supra.
} 
circumstances. ${ }^{18}$ The narrow issue to be decided was whether a temporary industry-wide lockout in response to a whipsaw strike could be lawful as a defense to preserve the employers' interest in group bargaining. ${ }^{10}$ In viewing the circumstances of the case, the Court stated that protected union activity is not so absolute as to deny self-help when legitimate employer-employee interests collide. ${ }^{20}$

The NLRB order and circuit court opinion in Brown are premised upon conflicting interpretations of Buffalo Linen. The Board considered Buffalo Linen to be an endorsement of its defensive test whereas the Tenth Circuit relied upon the broad sanction of selfhelp to preserve unity among association members. While support for either contention may be found in Buffalo Linen, ${ }^{21}$ it is probable that the Supreme Court adopted neither position without reservation, but indicated that each lockout case should be considered in terms of its particular economic circumstances. ${ }^{22}$

In examining attendant economic consequences, it is funda-

19 Prohibitions upon the right to "strike or lockout" under specified circumstances constitute the only reference to lockouts in the Taft-Hartley Act. $\$ \S 8(d)(4), 203,206$, 208, 61 Stat. 143, 154, 155 (1947), 29 U.S.C. $\$ \S 158$ (d) (4), 173, 176, 178 (1958). From these provisions and a congressional reluctance to expressly hold all lockouts illegal, the Court by negative implication assumed that the lockout may be legitimately used under certain circumstances. 353 U.S. at 92-93.

The Court also officially sanctioned the multi-employer association as a legitimate employer approach to the bargaining process. In viewing these associations as "a vital factor in the effectuation of the national policy of promoting labor peace through strengthened collective bargaining," the Court took cognizance of the fact that such associations were in existence long before the National Labor Relations Act (Wagner Act) of 1935, but that neither the Wagner Act nor Taft-Hartley sought to prohibit them. 353 U.S. at 95 .

10353 U.S. at 93.

so 353 U.S. at 96. The issue raised in Brown was not reached in Buffalo Linen, as the employers had not attempted to continue operations with replacements after the lockout. Buffalo Linen, confined to the decision of a narrow issue, did not define broader limitations which might be imposed upon the lockout privilege.

${ }^{21}$ Supreme Court acceptance of the Board's defensive test may be found in Buffalo Linen when the Court defined the narrow issue. 353 U.S. at 93 . It can also be found by implication, as the Court in Buffalo Linen approved the decision of the NLRB which had invoked the defensive language to justify a multi-employer lockout. Recent case law tends to support the defensive limitation. NLRB v. Anchorage Businessmen's Ass'n, 289 F.2d 619 (9th Gir. 1961) (lockout cannot be used against union employees only); Quaker State Oil Ref. Corp. v. NLRB, 270 F.2d (3rd Cir.), cert. denied, 361 U.S. 917 (1959) (single employer cannot use lockout offensively); American Brake Shoe Co. v. NLRB, 244 F.2d 489 (7th Cir. 1957). See Koretz, supra note 14, at 44 (1957); Extension of Employer Right to Lock Out, 50 Nw. U. L. REv. 240 (1955); 71 HaRv. L. REv. 182 (1957); cf., 76 HARv. L. REv. 1494, I497 (1963).

Rejection of the defensive test in favor of the broader "self-help" right also has support in Buffalo Linen, 353 U.S. at 96. Accord, NLRB v. Great Falls Employers' Council, Inc., 277 F.2d 772, 776 (9th Cir. 1960); 37 N.Y.U.L. REv. 1152 (1962).

22353 U.S. at 97; 57 Colum. L. Rev. 1172 (1957); 36 Texas L. Rev. 105 (1957). 
mental that both parties to an employment relationship seek to derive a benefit. The threat of a strike or lockout induces both parties to remain at the conference table as long as possible, for when the employee strikes he sacrifices his primary beneficial interest in wages to deprive the employer of his correlative production benefit. $^{23}$

The right to strike includes the power to determine when and where production shall cease. ${ }^{24}$ The multi-employer lockout, however, reverses the pattern as employers deprive the union of its advantage in exercising the strike initiative. In essence they renounce. a usual concern for production in favor of a transitory, but ligitimate interest in group economic unity. When immediately thereafter the employers attempt to reassert their production interest by hiring temporary replacements, they have sacrificed a minimum of economic benefit while maximizing the pressure upon their employees. The defensive test invoked by the NLRB has validity in that it prohibits an employer from voluntarily severing the employment relationship without accepting a substantial economic detri. ment. ${ }^{25}$

The Brown case has rejected the defensive test as a per se rule implying discriminatory intent. To protect both the struck employer's interest in continued production and the nonstruck associates' concern for unity, the majority held that the pursuit of both legiti-

\footnotetext{
${ }^{3}$ In order to preserve their respective benefits in the event of a future strike or lockout, unions may build up unemployment funds while management may specd up orders, stockpile, or subcontract.

24 Thus, unions will generally attempt to call strikes at a time when the cmployer can least afford a halt in production. Two examples are summer strikes among construction trades, and pre-Christmas strikes in the newspaper industry.

25. The Supreme Court has declared that "the presence of economic weapons in reserve" is the best means of insuring strengthened collective bargaining. NLRB v. Insurance Agents' Int'1 Union, 36I U.S. 477, 489 (1960). Generally speaking, a strike or lockout is only used as a weapon of last resort because the party initinting such action stands to lose as much, if not more, from a shutdown as his opponcnt. The necessity of examining and accepting the consequences of using a weapon of last resort is what makes genuine negutiations possible. If the detriment of a loss in production is removed from the lockout, employers would no longer be faccd with the necessity of weighing wage demands against continued production, but would be free from the responsibility which produces a bargaining attitude in the true sense of the term. Twentieth CENTURY Fund, STRIkes AND DEMocratic Govennment 18 (1947); see Hazard, A Management View of Wage Setting, ReAdings in Economics 291 (3d ed. 1958).

The inherent danger in Brown is that the authorization of a lockout frce from a substantial loss of production may tempt individual employers into a violation of $\S 8(a)(5)$ of the Taft-Hartley Act for a failure to bargain in good faith. Sce note 4 supra.
} 
mate interests permits the combined use of supplementing economic weapons by all employers. It should be recognized that the lockoutreplacement combination is not expressly rooted in legal precedent, as Mackay only applied to economic strikers, and Buffalo Linen was limited to a total shutdown situation.

The sole justification for the Brown decision therefore, must rest upon the Tenth Circuit's opinion that the NLRB offers the employer unit a choice which, by implication, unlawfully denies the right to lockout in the whipsaw context. ${ }^{26}$ The NLRB has contended that if the struck member replaces, nonstruck associates can continue operating without imposing significant detriment upon the struck member. The circuit court contraposed that this would deter others from exercising the defensive lockout, and thus the whipsaw would continue its inescapable prospect of success. The latter view overlooks the possibility that if the struck member can hire a sufficient number of capable replacements, both unity and production interests are in fact preserved-hence the lockout privilege is obviated by an equal competitive standing among all employers. ${ }^{27}$

Furthermore, if the struck employer cannot locate enough skilled replacements to place him on an economic par with nonstruck employers, Brown suggests that to preserve bargaining unity, all employers should be permitted to lockout, replace, and thereby subsist on an equal level of partial efficiency. However, if one employer cannot locate satisfactory replacements, it is not reasonable to assume that all employers will be able to locate even subsistencelevel replacements. This fact is strikingly illustrated in Brown since one nonstruck member was in fact unable to continue operations with replacements after locking out.

\footnotetext{
20319 F.2d at 11.

${ }^{27}$ In many industries replacements may vault the struck member right back into competition. This is more apt to occur where labor is relatively unskilled or where a struck employer's customers are not deterred by picketing. Under these circumstances unity may be retained without rendering all employees jobless, hence the lockout-replacement procedure is clearly unnecessary.

On the other hand, replacements may be insufficient in number or lacking in required training. Thus where effective replacement is not possible, one must examine the economic consequences of permitting nonstruck members to use temporary replacements in order to ascertain whether the need for unity is satisfied.

Where a picket line materially affects the struck employer's ability to retain a competitive status, the problem of preserving unity is not alleviated by industry-wide replacements as one employer alone remains picketed. Unity is impossible despite the unlikely existence of enough replacements for the entire association. See generally, Meltzer, Single-Employer and Multi-Employer Lockouts Under the Taft-Hartley Act, 24 U. GH. L. REv. 70 (1956).
} 
The Tenth Circuit correctly assumed that a consideration of the overriding interest in association unity may justify inherently discriminatory activity. ${ }^{28}$ But one must do more than merely ascertain the existence of a legitimate interest, for it is imperative that the procedure in question actually promote that interest. If the struck member can obtain adequate replacements, there is no need to lockout, for unity is maintained. If he cannot, unity will not be preserved if some, but not all, members replace and operate at a subsistence level. The individual members must decide whether unity or production is of paramount immediate interest.

When a struck member replaces after fellow employers have exercised the defensive lockout, the sincerity of that member in maintaining economic unity of condition is to be doubted. Courts should not overemphasize a need for unity when individual employers appear more concerned with continuing their operations than with preserving a common interest. As a final word of caution, the ultimate employer concern for profit-maximization remains unfulfilled in Brown if all must operate at a suboptimum level of production. Under these circumstances only the stronger members will survive a prolonged whipsaw, and the multi-employer association's avowed purpose of strengthening bargaining unity would be defeated. ${ }^{29}$ It would be better for employers to remain totally inoperative as a group, or to reinstate union clerks when the struck associate hires sufficient replacements.

In the final analysis, Brown poses the problem of reconciling interests among members of a multi-employer association. Buffalo Linen sanctions the lockout when necessary to preserve the association from threatened disintegration. Extending the lockout privilege to a supplementary right of replacement is not necessary to preserve unity nor inclined, upon practical analysis, to prevent threatened disintegration. The Tenth Circuit has held that the Board's decision was in error, whereas a conclusion more in keeping with the philosophy of the act would have been that the lockoutreplacement procedure constitutes an unwarranted interference with protected union activity.

$28319 \mathrm{~F} .2 \mathrm{~d}$ at 11 ; see note 8 supra.

${ }_{20}$ The entire justification for the lockout-replacement procedure in Brown rests with the statement that "the preservation of the multi-employer bargain [sic.] unit ... is necessary to assure economic justice." $319 \mathrm{~F} .2 \mathrm{~d}$ at 11 . 